\title{
Disposition and toxicity of trabectedin (ET-743) in wild-type and $m$ drl gene (P-gp) knock-out mice
}

\author{
J. H. Beumer • N. E. Franke • R. Tolboom • T. Buckle • \\ H. Rosing • L. Lopez-Lazaro • J. H. M. Schellens • \\ J. H. Beijnen • O. van Tellingen
}

Received: 12 January 2009 / Accepted: 12 February 2009 /Published online: 24 February 2009

(C) Springer Science + Business Media, LLC 2009

Summary Trabectedin is a novel anticancer drug active against soft tissue sarcomas. Trabectedin is a substrate for P-glycoprotein (P-gp), which is encoded by $m d r l a / 1 b$ in rodents. Plasma and tissue distribution, and excretion of $\left[{ }^{14} \mathrm{C}\right]$-trabectedin were evaluated in wild-type and $m d r 1 a / 1 b$

J. H. Beumer $\cdot$ H. Rosing $\cdot$ J. H. Beijnen

Department of Pharmacy and Pharmacology,

Slotervaart Hospital/The Netherlands Cancer Institute,

Louwesweg 6,

1066 EC Amsterdam, The Netherlands

N. E. Franke $\cdot$ R. Tolboom $\cdot$ T. Buckle $\cdot$ O. van Tellingen

Department of Clinical Chemistry,

The Netherlands Cancer Institute/Antoni

van Leeuwenhoek Hospital,

1066 CX Amsterdam, The Netherlands

\section{Lopez-Lazaro}

PharmaMar, Clinical Pharmacology,

Colmenar Viejo,

Madrid, Spain

\section{J. H. M. Schellens $\cdot$ J. H. Beijnen}

Department of Biomedical Analysis,

Division of Drug Toxicology, Faculty of Pharmaceutical Sciences,

Utrecht University,

Utrecht, The Netherlands

\section{J. H. M. Schellens}

Department of Medical Oncology,

Antoni van Leeuwenhoek

Hospital/The Netherlands Cancer Institute,

Amsterdam, The Netherlands

J. H. Beumer $(\triangle)$

Hillman Cancer Center, Research Pavilion,

University of Pittsburgh Cancer Institute,

Room G27D, 5117 Centre Avenue,

Pittsburgh, PA 15213-1863, USA

e-mail: beumerjh@upmc.edu
$(-/-)$ mice. In parallel, we investigated the toxicity profile of trabectedin by serial measurements of blood liver enzymes and general pathology. $\left[{ }^{14} \mathrm{C}\right]$-trabectedin was extensively distributed into tissues, and rapidly converted into a range of unknown metabolic products. The excretion of radioactivity was similar in both genotypes. The plasma clearance of unchanged trabectedin was not reduced when P-gp was absent, but organs under wild type circumstances protected by P-gp showed increased trabectedin concentrations in $m d r l a / 1 b(-/-)$ mice. Although hepatic trabectedin concentrations were not increased when P-gp was absent, $m d r l a / 1 b(-/-)$ mice experienced more severe liver toxicity. P-gp plays a role in the in vivo disposition and toxicology of trabectedin.

Keywords Trabectedin · P-gp · Knock-out · Mice ·

Mass balance $\cdot$ Disposition

\section{Introduction}

Trabectedin (ET-743, Yondelis ${ }^{\mathrm{TM}}$ ) belongs to the ecteinascidins, which are tetrahydro-isoquinoline compounds isolated from the marine tunicate Ecteinascidia turbinata [1-3]. Intravenous trabectedin (ET-743, Yondelis ${ }^{\mathrm{TM}}$, Fig. 1) is approved as monotherapy in Europe for use in patients with advanced soft tissue sarcomas (STS) after failure of anthracyclines and ifosfamide, or in patients who are unsuited to receive those agents [4]. Trabectedin has received orphan drug status for treating STS and for treating recurrent ovarian cancer in the United States and Europe [5].

Structurally, trabectedin is composed of three tetrahydroisoquinoline subunits and a central carbinolamine moiety, which enables it to bind covalently to DNA, see Fig. 1 [6]. 


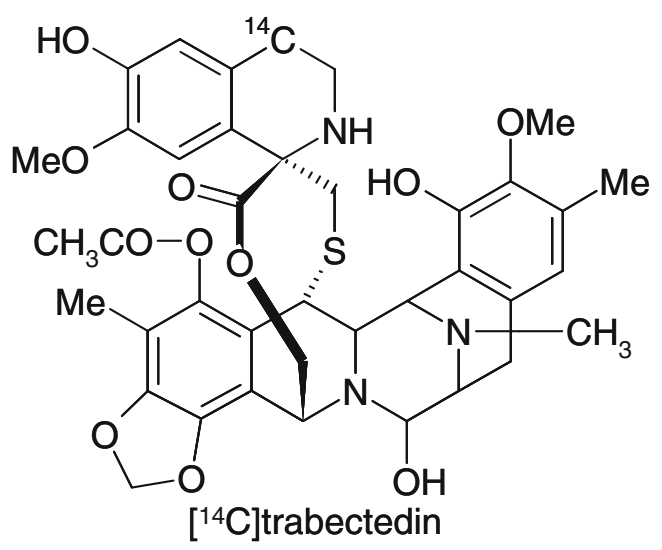

Fig. 1 Chemical structure of trabectedin and the position of the ${ }^{14} \mathrm{C}$ label in $\left[{ }^{14} \mathrm{C}\right]$ trabectedin

Trabectedin displays sequence-specific binding to the minor groove of duplex DNA, bending the double helix towards the major groove and affecting the transcription of genes, including the MDR1 gene $(A B C B 1)$ that codes for P-gp [7-11].

Trabectedin is a very potent compound. The approved dose is $1.5 \mathrm{mg} / \mathrm{m}^{2}$ every 3 weeks, resulting in total doses of approximately $3 \mathrm{mg}$ by i.v. infusion over $24 \mathrm{~h}$. These doses, in combination with a very large volume of distribution ( $\mathrm{V}_{\mathrm{ss}}, 1,000$ to $4,000 \mathrm{~L}$ [12]), result in plasma concentrations in the picogram to low nanogram per $\mathrm{mL}$ range. Trabectedin also displayed a large volume of distribution (Vss, 15-20 L/kg [13]) in laboratory animals. The excretory fate of trabectedin is largely unknown. In rats, less than $0.5 \%$ of the dose administered was recovered in bile as trabectedin, suggesting an important role for metabolism in the elimination of trabectedin [13]. Urinary excretion of trabectedin in man is reported to be less than $1 \%$ of the dose administered, and biliary excretion of unchanged trabectedin is also very low [14-16], indicating that metabolism is the major route of elimination. However, the pathways involved in the metabolism of trabectedin are largely unknown. Isolation of metabolites from biological matrices and further structural elucidation is very difficult because of their very low concentrations [15]. Metabolic and degradation products were identified after incubation with human serum, liver microsomes, and UDP-glucuronyl transferase [14], and in vitro studies with liver microsomes suggest that trabectedin is mainly metabolized by CYP3A4 and to a minor extent by CYPs 2C9, 2C19, 2D6 and 2E1 [13, 17].

Although clinically, dose-limiting toxicities are primarily related to the effects of trabectedin on bone marrow, hepatotoxicity, as manifested by transient elevation of serum liver enzymes, is frequently observed with all administration schedules [12]. The biochemical basis of the liver toxicity is unknown. Intriguingly, the magnitude of the elevation of liver enzymes diminishes after repeated cycles. A possible explanation is that there are changes in the expression of enzymes or transporters involved in elimination of trabectedin and/or its metabolites.

Recent in vitro investigations in our institute have shown that trabectedin is a P-gp substrate; however, P-gp only confers resistance to trabectedin when expressed at high levels [18], and there are reports suggesting resistance to trabectedin by non-P-gp related pathways [19, 20], including a deficiency in transcription-coupled nucleotideexcision repair [21].

Besides the association of P-gp expression with reduced cytotoxicity in tumor cells and with therapeutic failure, P-gp can also play an important role in the plasma pharmacokinetics and tissue distribution of its substrates [22-27]. P-gp is expressed at high levels at specific organbarriers like the blood-brain barrier, the blood-testis barrier, and the blood-placenta barrier and limits the entry of substrate drugs into these sanctuary sites. Moreover, P-gp is expressed in organs like the gut, liver and kidneys where it is involved in the excretion of drugs from the body [27]. Therefore, we designed a study using P-gp-deficient $(m d r l a / 1 b(-/-))$ mice [23] to explore the role of P-gp in the disposition and toxicity of trabectedin in vivo.

\section{Materials and methods}

\section{Drugs and chemicals}

$\left[{ }^{14} \mathrm{C}\right]$ trabectedin, provided by PharmaMar (Madrid, Spain), originated from Biodynamics Radiochemicals (Billingham, UK) and was purified by HPLC to $>97.5 \%$ radiochemical purity [16]. Non-labelled trabectedin was provided as lyophilized product for injection by PharmaMar. $\left[\mathrm{D}_{6}\right]$ trabectedin was provided by PharmaMar (Madrid, Spain).

Bovine serum albumin fraction V (BSA) was obtained from Roche Diagnostics GmBH (Mannheim, Germany). Water was purified by the Milli-Q Plus ${ }^{\circledR}$ system (Millipore, Milford, USA). All other chemicals were of analytical grade.

Animals

FVB wild-type (WT) and P-gp knock-out type (mdrlab(-/-)) mice, 9-14 weeks of age, were housed and handled in accordance with Dutch national law. The animals had access to food (Hope Farms B.V., Woerden, The Netherlands) and acidified water ad libitum. All experiments were approved by the local ethics committee for animal experiments.

\section{Maximum tolerable dose}

To establish the single administration maximum tolerable dose (MTD) of trabectedin, groups (6 mice each) of male 
and female wild-type and $m d r l a / 1 b(-/-)$ mice were dosed at $50,100,150,200,250$ and $300 \mu \mathrm{g} / \mathrm{kg}$ and monitored for 14 days. Mice were euthanized upon loss of $20 \%$ of the initial body weight, and counted as a toxic death. The MTD was defined as the highest dose level where none of 6 mice died as a consequence of the drug, loss of body weight of individual mice did not exceed $20 \%$, or the average loss of body weight in the group did not exceed $15 \%$.

\section{Hepatotoxicity}

To investigate the role of P-gp in the hepatotoxicity of trabectedin, male and female wild-type and $m d r 1 a / 1 b(-/-)$ mice (9 mice per group) were dosed at their respective MTD. Female mdrla/lb(-/-) mice were also dosed at $150 \mu \mathrm{g} / \mathrm{kg}$, which is below their MTD, to allow comparison with male $m d r l a / 1 b(-/-)$ mice. The liver function parameters alanine aminotransferase (ALAT/SGPT), aspartate aminotransferase (ASAT/SGOT), total bilirubin and alkaline phosphatase (AP) were monitored daily for up to 7 days by serial blood sampling. Jaundice was defined as macroscopic observation of yellow-colored skin of the mice. Blood samples were collected in heparinized glass capillaries and transferred into polypropylene vials followed by centrifugation $(10 \mathrm{~min}, 6,000 \times \mathrm{g})$. A $20-25 \mu \mathrm{l}$ aliquot of plasma was diluted fourfold with saline and assayed the same day by a Hitachi 917 Analyzer (Roche Diagnostics, Indianapolis, IN, USA) using standard protocols.

\section{Pathology}

Autopsies were performed at day 4 or day 14 after trabectedin administration at the respective MTD $(\mathrm{N}=2$ per group). Expert pathology reports were prepared by a trained animal Pathologist of the Netherlands Cancer Institute.

\section{Tissue disposition}

To investigate the tissue distribution of $\left[{ }^{14} \mathrm{C}\right]$ trabectedin, we dosed male wild-type and mdrla/1b(-/-) mice with $150 \mu \mathrm{g} / \mathrm{kg}\left[{ }^{14} \mathrm{C}\right]$ trabectedin. At $7 \mathrm{~min}, 20 \mathrm{~min}$, and 1,3 , $8,24,48$ and $96 \mathrm{~h}$ after administration, 4 animals of each genotype were exsanguinated by cardiac puncture under methoxyflurane (Medical Developments, Springvale, Australia) anesthesia and euthanized by cervical dislocation. The tissues dissected for analysis of radioactivity included: plasma (from blood from the heart), brains, muscle (from the back), abdominal fat, colon, cecum, small intestine, stomach (all emptied), liver, gallbladder, kidneys, lungs, spleen, heart, thymus, abdominal lymph nodes, testes, epidydimus, adrenal glands, bone, skin and pancreas.
Tissues that were only analyzed for total radioactivity content were weighed and dissolved in $1 \mathrm{~mL}$ Solvable tissue solubilizer (Packard, Groningen, The Netherlands), followed by quantitation of radioactivity. Other tissues were analyzed for both total radioactivity and parent drug, and were weighed and homogenized in $2 \mathrm{~mL}$ of a $4 \%$ bovine serum albumin solution in water. Brains and liver were homogenised in 3 and $5 \mathrm{~mL}$, respectively, and plasma was diluted with at least 1 volume of $4 \%$ BSA. A $200-\mu \mathrm{L}$ aliquot of each homogenate was analyzed for radioactivity by liquid scintillation counting after addition of $4 \mathrm{~mL}$ of Ultima Gold scintillation fluid (Packard, Groningen, The Netherlands). Counting was performed using a Tricarb 2300 TR Liquid Scintillation Analyzer (Packard, Meriden, CT, USA) with automating quench correction.

Tissues homogenized with 4\% BSA were assayed for trabectedin concentration using an adapted validated LCMS/MS method [28]. After addition of [ $\left[\mathrm{D}_{6}\right]$-trabectedin as internal standard, $500 \mu \mathrm{L}$ aliquots of homogenate were extracted twice with $5 \mathrm{~mL}$ of diethyl ether. Pooled organic layers were evaporated to dryness under a gentle stream of nitrogen, and stored at $-20^{\circ} \mathrm{C}$ until analysis. Reconstitution was performed by vortexing and sonication $(5 \mathrm{~min})$ with $200 \mu \mathrm{L}$ of methanol-5 $\mathrm{mM}$ ammonium acetate, $0.4 \%$ formic acid $(75: 25, v / v)$ (the mobile phase). Quantitation was performed using $\left[{ }^{14} \mathrm{C}\right]$ trabectedin calibration samples (spiked to the respective blank tissue homogenate), that had been processed identically to the samples. Recovery was between 50 and $80 \%$, and the lower limit of quantitation (LLQ) was $50-100 \mathrm{pg} / \mathrm{mL}$ homogenate, depending on the specific tissue involved.

\section{Excretion}

The excretion of $\left[{ }^{14} \mathrm{C}\right]$ trabectedin was studied in wild-type and $m d r l a / 1 b(-/-)$ male mice ( $N=4$ per genotype) placed in Ruco Type M/1 metabolic cages (Valkenswaard, The Netherlands). At 8, 24, 48, 72 and $96 \mathrm{~h}$ after $\left[{ }^{14} \mathrm{C}\right]$ trabectedin administration, urine and feces were collected, Urine and feces samples were weighed, and feces were homogenized in 10 parts 4\% BSA. Radioactivity determination of the dosing solution and the biological samples was performed by liquid scintillation counting after addition of $4 \mathrm{~mL}$ (to $200 \mu \mathrm{L}$ urine) or $12 \mathrm{~mL}$ (to $200 \mu \mathrm{L}$ feces homogenate or $100 \mu \mathrm{L}$ of dosing solution 1:20) Ultima Gold scintillation fluid.

\section{Metabolism}

The metabolism of trabectedin was investigated by gallbladder cannulation [29] of a single WT mouse (male, 13 weeks). Bile was collected for $1.5 \mathrm{~h}$ following intravenous administration of $200 \mu \mathrm{g}\left[{ }^{14} \mathrm{C}\right]$-trabectedin $/ \mathrm{kg}$ body 
weight. A $20-\mu \mathrm{L}$ aliquot of bile was diluted 20 -fold in methanol:phosphate buffered saline $(1: 10, v / v)$ followed by extraction with $4 \mathrm{~mL}$ of diethylether. After shaking (5 min), the aqueous layer was frozen using ethanol and dry-ice. The organic layer was separated and evaporated to dryness under a gentle stream of nitrogen followed by reconstitution in $400 \mu \mathrm{L}$ of methanol:phosphate buffered saline $(1: 10, v / v)$. The aqueous phase was diluted $(1: 1, v / v)$ with methanol: phosphate buffered saline $(1: 10, v / v)$. Each solution was injected onto a Symmetry C18 column $(150 \times 4.6 \mathrm{~mm}$, $3.5 \mu \mathrm{m}$, Waters, Milford, USA). A binary gradient was applied at $1 \mathrm{~mL} / \mathrm{min}$ using two Spectroflow SF400 pumps (Kratos, Ambacht, The Netherlands). Mobile phase A consisted of $10 \mathrm{mM}$ ammonium acetate $+0.04 \%$ formic acid $(\mathrm{pH}=4.0)$, and mobile phase $\mathrm{B}$ consisted of methanol:10 mM ammonium acetate $+0.04 \%$ formic acid $(30: 70, v / v)$. An 18-min linear gradient from $43 \%$ to $100 \% \mathrm{~B}$ was followed by $100 \%$ B until $23 \mathrm{~min}$. Eluate fractions were collected every $18 \mathrm{~s}$. After addition of $3 \mathrm{~mL}$ scintillation fluid, radioactivity was determined off-line by liquid scintillation counting.

\section{Data analysis}

AUC values were calculated in Excel (Microsoft Corporation, Redmond, WA) based on the linear trapezoidal rule. Statistical analysis of AUC values consisted of calculation of the mdrla/ $1 b(-/-)$ to wild-type AUC ratio with the associated standard error (SE). After log-transformation, these ratios were subjected to a two-sided Students t-test, under the nullhypothesis of $\log ($ AUC-ratio $)=0$.

Excretion of radioactivity in urine, feces, and the total excretion of $\left[{ }^{14} \mathrm{C}\right]$-trabectedin in $m d r l a / 1 b(-/-)$ and wild-type male mice was compared with a two-sided Students t-test.

A value of $p<0.05$ was considered statistically significant.

\section{Results}

Maximum tolerable dose

The MTD of trabectedin was $250 \mu \mathrm{g} / \mathrm{kg}$ in both male and female wild-type mice. However, we observed a sex-based difference in the mdrla/lb(-/-) mice. Male mice were more sensitive, as the MTD was $150 \mu \mathrm{g} / \mathrm{kg}$ whereas the MTD in females was $250 \mu \mathrm{g} / \mathrm{kg}$, see Table 1. Mice receiving trabectedin at dose levels exceeding the MTD suffered from general malaise (manifested by inactivity and pilo-erection) which most likely caused insufficient food and fluid intake. Animals were euthanized when their body weight loss exceeded 20\%. Other macroscopic signs of toxicity were mild alopecia behind the ears of female $m d r l a / 1 b(-/-)$ mice, and occasional jaundice, particularly in male $m d r 1 a / 1 b(-/-)$ mice.
Table 1 Determination of the maximum tolerable dose (MTD) of trabectedin in male and female wild-type and $m d r l a / 1 b(-/-)$ mice

\begin{tabular}{|c|c|c|c|c|c|c|c|c|}
\hline \multirow{3}{*}{$\begin{array}{l}\text { Dose } \\
\mu \mathrm{g} / \mathrm{kg}\end{array}$} & \multicolumn{4}{|c|}{ Wild-type } & \multicolumn{4}{|c|}{$m d r l a / 1 b(-/-)$} \\
\hline & \multicolumn{2}{|c|}{ Male } & \multicolumn{2}{|c|}{ Female } & \multicolumn{2}{|c|}{ Male } & \multicolumn{2}{|c|}{ Female } \\
\hline & $N$ & $\dagger$ & $N$ & $\dagger$ & $N$ & $\dagger$ & $N$ & $\dagger$ \\
\hline 50 & 3 & 0 & 7 & 0 & - & - & - & - \\
\hline 100 & 3 & 0 & 7 & 0 & 3 & 0 & - & - \\
\hline 150 & 3 & 0 & 7 & 0 & 6 & 0 & 3 & 0 \\
\hline 200 & 3 & $1^{\mathrm{a}}$ & 7 & 0 & 3 & 2 & 3 & 0 \\
\hline 250 & 6 & 0 & 6 & $1^{\mathrm{b}}$ & 3 & 3 & 6 & 0 \\
\hline 300 & 3 & 1 & 3 & 1 & 3 & 3 & 3 & 1 \\
\hline 350 & 3 & 3 & 3 & 2 & - & - & - & - \\
\hline MTD & 250 & $\mu \mathrm{g} / \mathrm{kg}$ & 250 & $\mu \mathrm{g} / \mathrm{kg}$ & 150 & $\mu \mathrm{g} / \mathrm{kg}$ & 250 & $\mu \mathrm{g} / \mathrm{kg}$ \\
\hline
\end{tabular}

${ }^{a}$ This death was not considered drug-related as it showed an atypically sharp decline in body-weight starting the day of administration

${ }^{\mathrm{b}}$ This death was excluded as the mouse suffered from a tailinflammation at the site of injection

\section{Hepatotoxicity}

Elevation of liver enzymes is common after administration of trabectedin to cancer patients. The biochemical basis of this hepatotoxicity is unknown. In this study, we have explored the role of P-gp in the hepatotoxicity of trabectedin in mice by serial determination of liver enzymes in plasma. None of the mice in these series experienced more than $20 \%$ loss of body weight during the observation period, and the toxicity profile was similar to that in the mice used for the determination of the MTD. Only male and female $m d r l a / 1 b$ $(-/-)$ mice displayed mild jaundice. Levels of plasma ALAT, ASAT, bilirubin, and AP are presented in Fig. 2. Given the large inter-animal variability in plasma liver enzyme elevations, the number of animals used did not allow rigorous statistical analysis between all groups. In general, ALAT, ASAT and bilirubin levels increased at $24 \mathrm{~h}$ after dosing, reached a maximum within approximately 3 days, and returned to baseline levels after approximately 1 week. Plasma levels of AP started to increase after $48 \mathrm{~h}$, and reached a maximum at 4 days after dosing. On an opportunistic basis we re-dosed a cohort of male wild-type and female $m d r l a / 1 b(-/-)$ mice with $250 \mu \mathrm{g} / \mathrm{kg}$ trabectedin, 6 weeks after the first dose. This resulted in a slightly increased hepatotoxicity pattern in the female $m d r 1 a / 1 b(-/-)$ mice, whereas hepatotoxicity was decreased in the male wild-type mice.

Pathology

Bone marrow was depleted in all the mice euthanized 4 days after dosing, but had recovered by day 14 . Small 

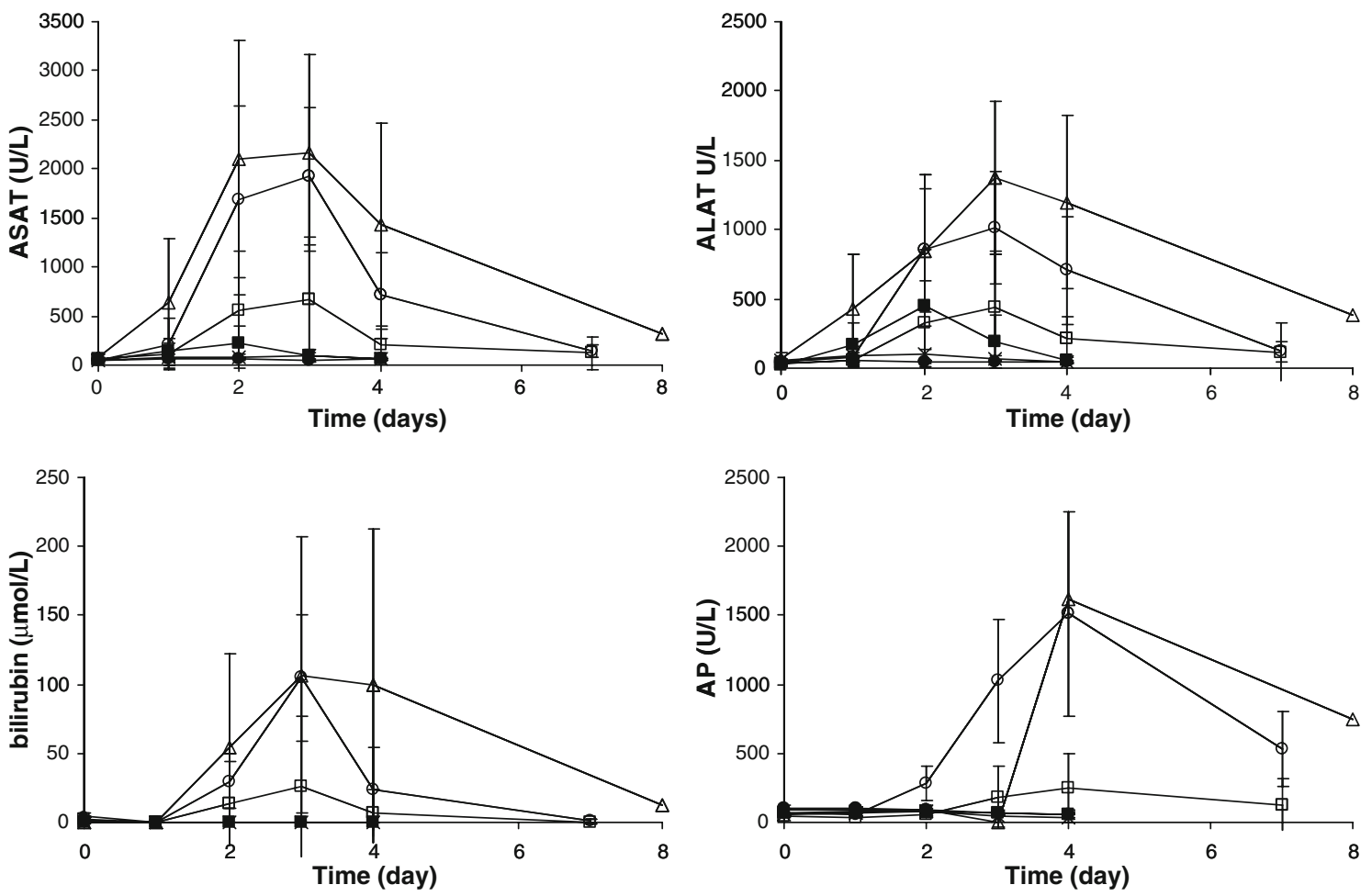

Fig. 2 Changes in plasma liver enzyme concentrations (mean \pm standard deviation) after administration of trabectedin to male (squares) and female (circles) wild-type (solid) and mdrla/lb(-/-) (open) mice. Bilirubin and AP were undetectable in wild-type males

and females. $A P$ alkaline phosphatase; On an opportunistic basis, male wild-type (X) and female mdrla/lb(-/-) mice (open triangle) were reinjected 6 weeks after the first dosing. $N=9$ per group

focal degeneration of hepatic tissue was observed in all male and female mdrla/lb(-/-) mice at both the day 4 and 14 time points, which in approximately half the cases was accompanied by signs of cholangitis and bile duct proliferation. Because this was a different cohort of mice than the mice used in the hepatotoxicity study, the presence of cholangitis and bile duct proliferation could not be correlated with biochemical parameters such as ALAT, ASAT, AP or bilirubin. In female $m d r l a / 1 b(-/-)$ mice only, degeneration of the kidney tubules and hypotrophic degeneration of the heart muscle were observed. In all of the female mdrla/1b(-/-) mice, the incisors showed degeneration of the dentine. Degeneration of the intervertebral discs was observed across all groups, apparently without a specific pattern.

Tissue disposition

P-gp can have a major impact on the disposition of substrate drugs such as trabectedin. We therefore investigated the effect of P-gp on $\left[{ }^{14} \mathrm{C}\right]$ trabectedin disposition. Results are shown in Fig. 3 and Table 1.

The total plasma radioactivity versus time profile after administration of $\left[{ }^{14} \mathrm{C}\right]$ trabectedin was similar in wild-type

and $m d r l a / 1 b(-/-)$ male mice. LC-MS/MS quantification of trabectedin in plasma revealed that trabectedin is rapidly metabolised. At $20 \mathrm{~min}$ and $3 \mathrm{~h}$ after administration, only about 40 and $10 \%$ respectively of the radioactivity in plasma represented unchanged trabectedin. The plasma concentration versus time profile of unchanged trabectedin in $m d r l a / 1 b(-/-)$ and wild-type mice were similar during the first hours after drug administration (Table 2).

The tissue-to-plasma ratios showed that radioactivity is extensively distributed from plasma to tissues, in both wildtype and $m d r 1 a / 1 b(-/-)$ mice. Tissue-to-plasma ratios of $\left[{ }^{14} \mathrm{C}\right]$ trabectedin were always larger than unity, except for the brain in wild-type mice. In most tissues, radioactivity was initially eliminated rapidly, followed by a slower terminal elimination phase. Exceptions were the spleen, thymus, lymph nodes, testis of both genotypes and the brain of $m d r l a / 1 b(-/-)$ mice, which displayed prolonged retention of radioactivity.

The effect of the absence of P-gp on the tissue distribution is most pronounced in the mdrla/1b(-/-) brain (13fold increase) and testis (twofold increase) relative to the wild-type controls. Differences were also observed in the small intestines, kidneys, and heart, all organs known to express P-gp [22-27]. 
a

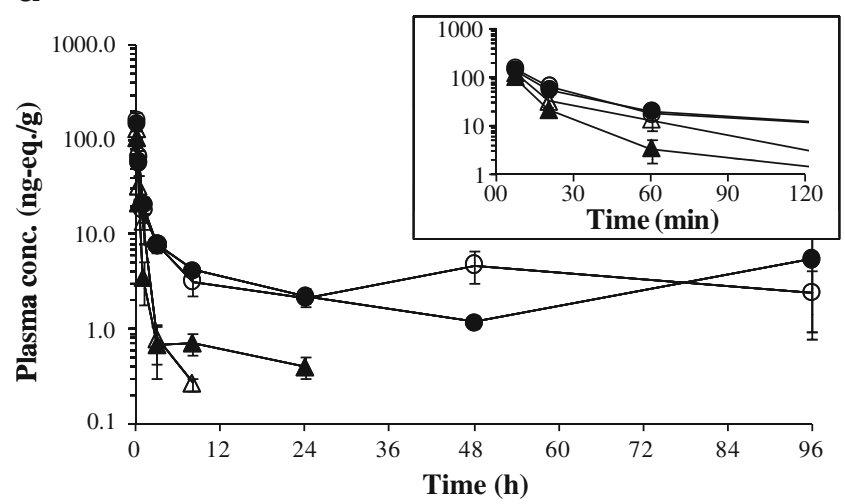

C

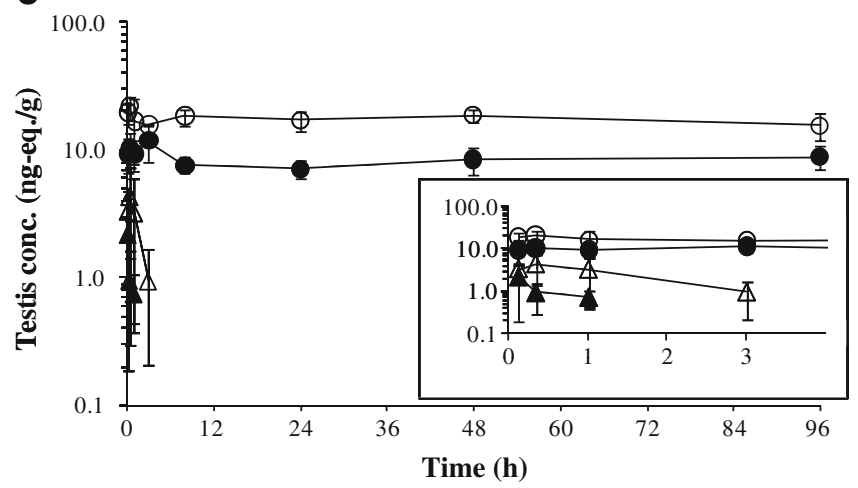

e

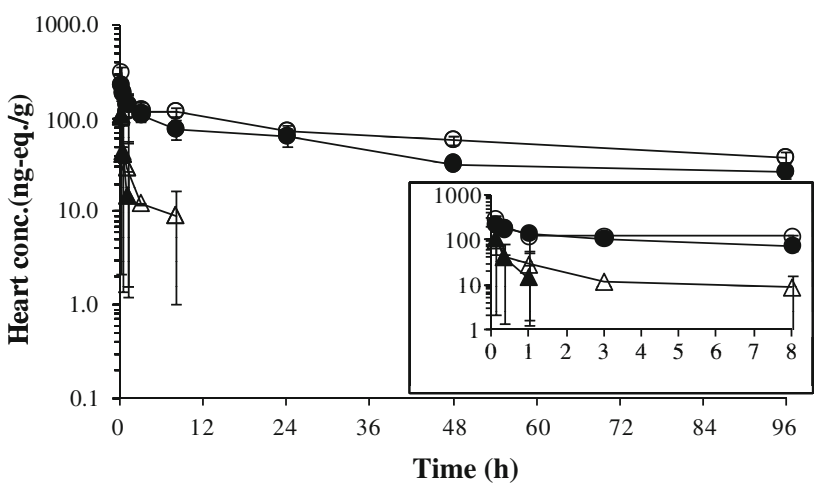

Fig. 3 Organ radioactivity $\left[{ }^{14} \mathrm{C}\right]$ trabectedin equivalents (circles) and unchanged trabectedin (triangles) concentration versus time curves in wild-type (closed) and mdrla/lb(-/-) (open) male mouse plasma (a),

LC-MS/MS quantitation of trabectedin in tissues showed that only a fraction of radioactivity was accounted for by unchanged compound. In brain at 7 min after dosing, trabectedin accounted for approximately $25 \%$ and $20 \%$ of radioactivity in $m d r l a / 1 b(-/-)$ and wild-type mice, respectively. Thereafter, trabectedin concentrations in wild-type brain fell below the LLQ while trabectedin concentrations were maintained at a higher level in $m d r l a / 1 b(-/-)$ brain. At $20 \mathrm{~min}$ after b

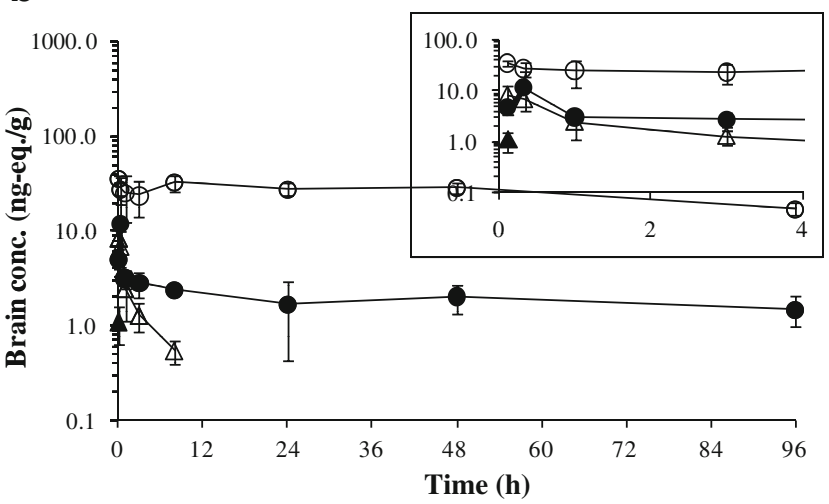

d

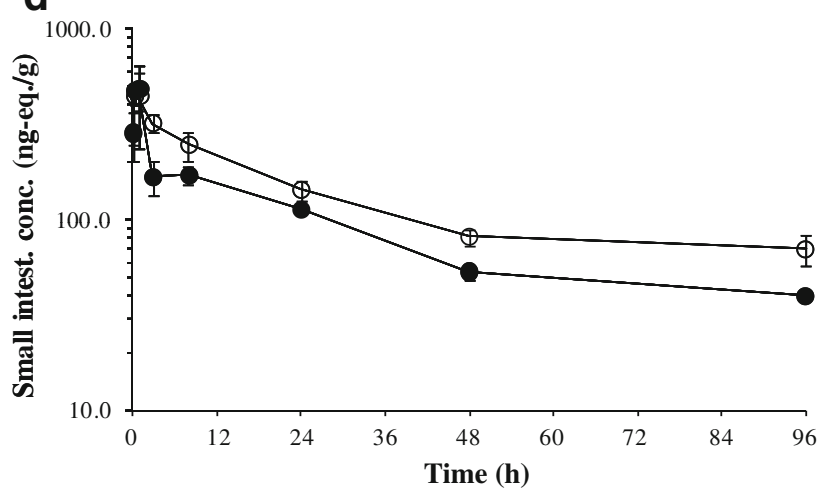

f

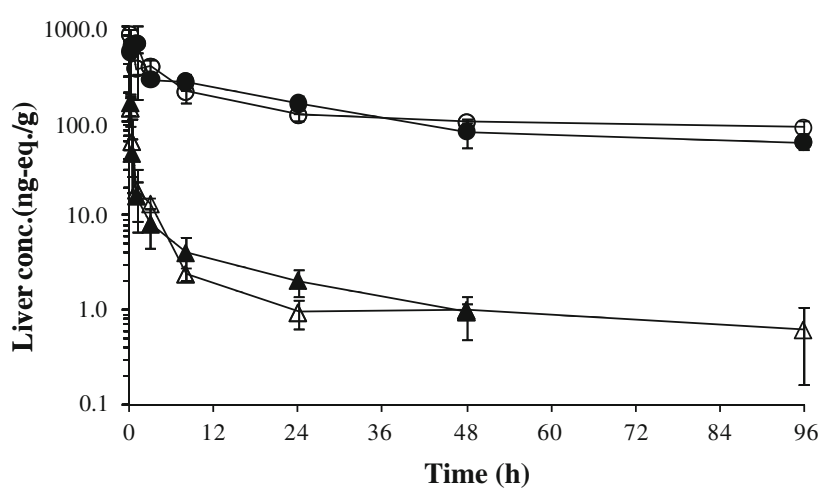

brain (b), testis (c), small intestines (d), heart (e), and liver (f). $N=4$ per time point per genotype

administration, trabectedin accounts for approximately $20 \%$ and $10 \%$ of testis radioactivity in $m d r l a / 1 b(-/-)$ and wild-type mice, respectively. The trabectedin ratio in $m d r l a / 1 b(-/-)$ to wild-type testis at that time point was approximately 4.5. Liver concentrations of trabectedin represented only $1.5 \%$ or less of radioactivity at $8 \mathrm{~h}$ after administration and were similar in $m d r l a / 1 b(-/-)$ and wild-type mice. These results indicate the importance of P-gp in trabectedin disposition. 
Table 2 Area under the tissue concentration versus time curves for radioactive $\left[{ }^{14} \mathrm{C}\right]$ trabectedin equivalents in wild-type and $m d r 1 a / 1 b(-/-)$ male mice, the respective tissue-to-plasma ratios and the $\mathrm{mdr} 1 \mathrm{a} / 1 \mathrm{~b}(-/-)$ to wild-type ratios

\begin{tabular}{|c|c|c|c|c|c|c|c|}
\hline \multirow[t]{2}{*}{ Organ } & \multicolumn{3}{|l|}{ Wild-type } & \multicolumn{3}{|l|}{$m d r l a / 1 b(-/-)$} & \multirow{2}{*}{$\begin{array}{l}m d r l a / 1 b(-/-) / \\
\text { wild-type ratio }\end{array}$} \\
\hline & AUC $(\mu \mathrm{g} \times \mathrm{h} / \mathrm{g})$ & SE & Tissue/plasma-ratio & AUC $(\mu \mathrm{g} \times \mathrm{h} / \mathrm{g})$ & SE & Tissue/plasma-ratio & \\
\hline Plasma & 0.371 & 0.055 & 1.0 & 0.420 & 0.039 & 1.0 & 1.1 \\
\hline Brains & 0.188 & 0.019 & 0.51 & 2.48 & 0.09 & 5.9 & $13.2 *$ \\
\hline Muscle & 2.07 & 0.09 & 5.6 & 2.88 & 0.46 & 6.8 & 1.4 \\
\hline Fat & 7.33 & 1.12 & 19.8 & 6.58 & 0.84 & 15.7 & 0.90 \\
\hline Colon & 74.8 & 5.1 & 202 & 85.6 & 5.2 & 204 & 1.14 \\
\hline Caecum & 133.9 & 18.7 & 361 & 120.3 & 12.2 & 286 & 0.90 \\
\hline Small intest. & 8.46 & 0.18 & 22.8 & 12.1 & 0.4 & 28.7 & $1.4^{* *}$ \\
\hline Stomach & 49.0 & 3.5 & 132 & 55.9 & 1.9 & 133 & 1.1 \\
\hline Liver & 12.2 & 0.7 & 32.8 & 12.2 & 0.4 & 29.1 & 1.0 \\
\hline Gallbladder & 555.1 & 123.7 & 1,498 & 426.4 & 84.9 & 1,015 & 0.77 \\
\hline Kidneys & 9.99 & 0.28 & 27.0 & 8.47 & 0.35 & 20.2 & $0.85^{* * *}$ \\
\hline Lungs & 15.8 & 0.9 & 42.6 & 18.1 & 1.0 & 43.1 & 1.2 \\
\hline Spleen & 36.2 & 1.1 & 97.6 & 30.1 & 3.3 & 71.6 & 0.83 \\
\hline Heart & 4.61 & 0.19 & 12.4 & 6.46 & 0.19 & 15.4 & $1.4^{* *}$ \\
\hline Thymus & 71.3 & 6.9 & 192 & 73.3 & 9.2 & 175 & 1.0 \\
\hline Lymph nodes & 99.06 & 22.92 & 267 & 127.9 & 8.0 & 304 & 1.3 \\
\hline Testes & 0.802 & 0.045 & 2.2 & 1.68 & 0.07 & 4.0 & $2.1^{* *}$ \\
\hline Epidymidus & 0.815 & 0.105 & 2.2 & 0.653 & 0.032 & 1.6 & 0.80 \\
\hline Adrenals & 5.16 & 0.41 & 13.9 & 5.62 & 0.72 & 13.4 & 1.1 \\
\hline Bone & 1.70 & 0.12 & 4.6 & 1.70 & 0.08 & 4.0 & 1.0 \\
\hline Skin & 2.37 & 0.22 & 6.4 & 3.11 & 0.32 & 7.4 & 1.3 \\
\hline Pancreas & 84.1 & 4.1 & 227 & 82.7 & 3.6 & 197 & 0.98 \\
\hline
\end{tabular}

${ }^{*} p<0.001$

$* * p<0.01$

$* * * p<0.05$

\section{Excretion and metabolism}

We determined the effect of P-gp on the excretion of $\left[{ }^{14} \mathrm{C}\right]$ trabectedin in wild-type and $m d r l a / 1 b(-/-)$ mice (Fig. 4). Feces was the predominant excretory pathway in both wildtype $(70.6 \pm 13.9 \%)$ and $m d r l a / 1 b(-/-)$ mice $(75.4 \pm 2.3 \%)$. The contribution of urinary excretion $(2.3 \pm 1.3 \%$ and $2.2 \pm$ $0.9 \%$, respectively) to total recovery $(72.9 \pm 13.1 \%$ and $77.6 \pm$ $2.5 \%$, respectively) was minimal.

No significant differences were observed in urinary, fecal or total excretion between the wild-type and $m d r 1 a / 1 b(-/-)$ mice $(\mathrm{P} \geq 0.50$ for fecal, urinary, and total excretion at all time points). Given the finding that only a small fraction of radioactivity in plasma and tissues was unchanged drug, we anticipated that unchanged trabectedin was only a minor component of the excreted radioactivity. In that intraintestinal degradation of trabectedin may occur, we fitted a single, male, wild-type mouse with a cannulated bile duct to investigate the composition of the excreted radioactivity in the bile (0-90 min sample). The resulting radiochromatogram is shown in Fig. 5 with trabectedin eluting at about $11.4 \mathrm{~min}$, and representing only about $2.5 \%$ of the total radioactivity of the bile sample. The total bile sample collected over $1.5 \mathrm{~h}$ contained approximately $1.6 \%$ of the radioactive dose administered. Because the concentration of the compounds in the sample was very low and the UV chromatogram of the fractionation (not shown) indicated the presence of large amounts of matrix-derived interferences, further structure analysis of fractions (e.g. by means of mass spectrometry) was not feasible. Trabectedin appeared to be extensively metabolised to a large number of more polar as well as less polar metabolites, and was itself only a minor contributor to biliary excretion, even within the first $1.5 \mathrm{~h}$ after dosing. 


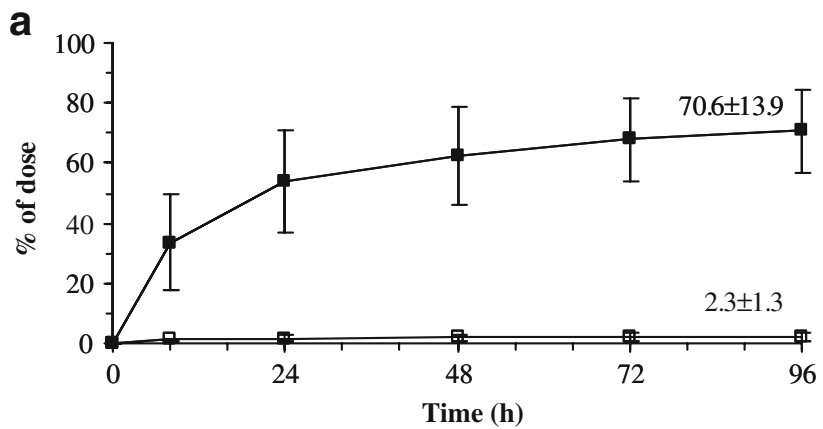

b

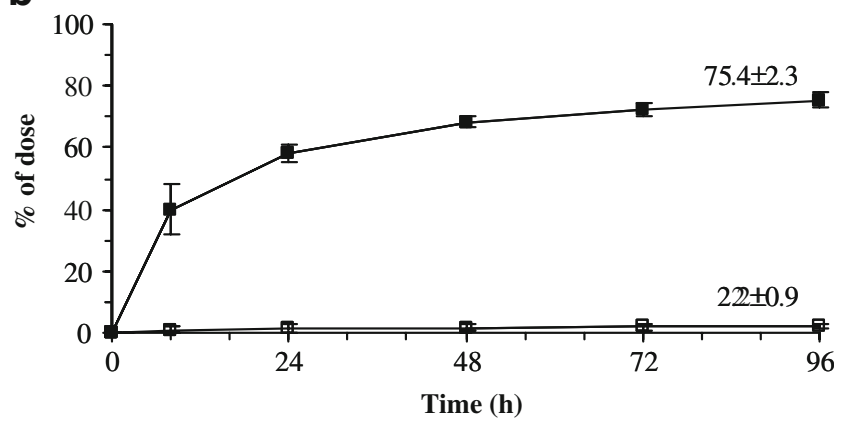

Fig. 4 Cumulative excretion (mean \pm SD) of total radioactivity in urine (open square) and feces (closed square) after IV administration of $\left[{ }^{14} \mathrm{C}\right]$ trabectedin to wild-type (a) and $m d r l a / 1 b(-/-)$ (b) male mice $(N=4$ per genotype $)$

\section{Discussion}

This study shows that the in vivo disposition of trabectedin is affected by P-gp. As expected, P-gp decreases the penetration of trabectedin into the brain and the testis as they are protected by a specific blood-organ barrier expressing P-gp. We also observed a decreased penetration of the heart, confirming earlier reports on doxorubicin disposition that suggest a role for P-gp in decreasing cardiac exposure to xenobiotics [24]. However, the effect of P-gp on trabectedin disposition in the heart is smaller than in the brain or testis because this organ is not shielded by a blood-organ barrier, although the heart endothelium does express P-gp.

In contrast to reports on other P-gp substrate drugs [30-32], we did not observe a decreased clearance of unchanged trabectedin in $m d r l a / 1 b(-/-)$ mice. The reason that the clearance is not reduced in mdrla/lb(-/-) mice may be that metabolic clearance is the most important route of elimination of trabectedin. As our data show, liver concentrations of total radioactivity and unchanged trabectedin are high and unaffected by P-gp status. Other P-gp substrates that do show a decreased clearance in $m d r l a / 1 b$ $(-/-)$ mice, are commonly excreted unchanged in substantial amounts by the liver or gut and a major part of this excretion is mediated by P-gp [29, 33]. As only a minor fraction of the radioactivity that was excreted into the bile of a wild-type mice represented unchanged trabectedin, the absence of P-gp in $m d r l a / 1 b(-/-)$ mice was probably unable to significantly decrease the trabectedin clearance.

In the disposition study, the male $m d r l a / 1 b(-/-)$ and wild-type mice received trabectedin at the same dose of $150 \mu \mathrm{g} / \mathrm{kg}$ and this resulted in similar plasma exposure. This dose, however, was not equitoxic to both strains as it was well below the MTD of wild-type mice but at the MTD of the $m d r l a / 1 b(-/-)$ mice. Therefore, the difference in the MTD between male $m d r l a / 1 b(-/-)$ and male wild-type mice cannot satisfactorily be explained by a difference in plasma exposure to trabectedin. Similarly, while there was no difference in the trabectedin accumulation in the liver between the two strains, we did observe a more severe hepatotoxicity in the mdrla/lb(-/-) mice. The absence of a clear relationship between plasma and liver exposure to trabectedin and toxic effects might suggest that metabolites of trabectedin are involved in the toxicity, and that they

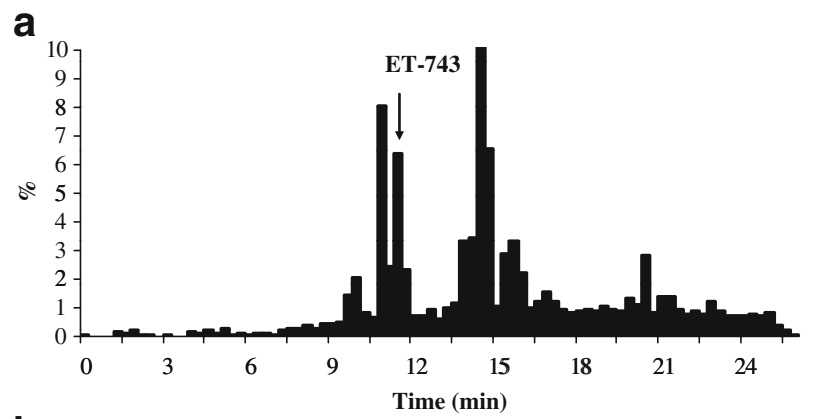

b
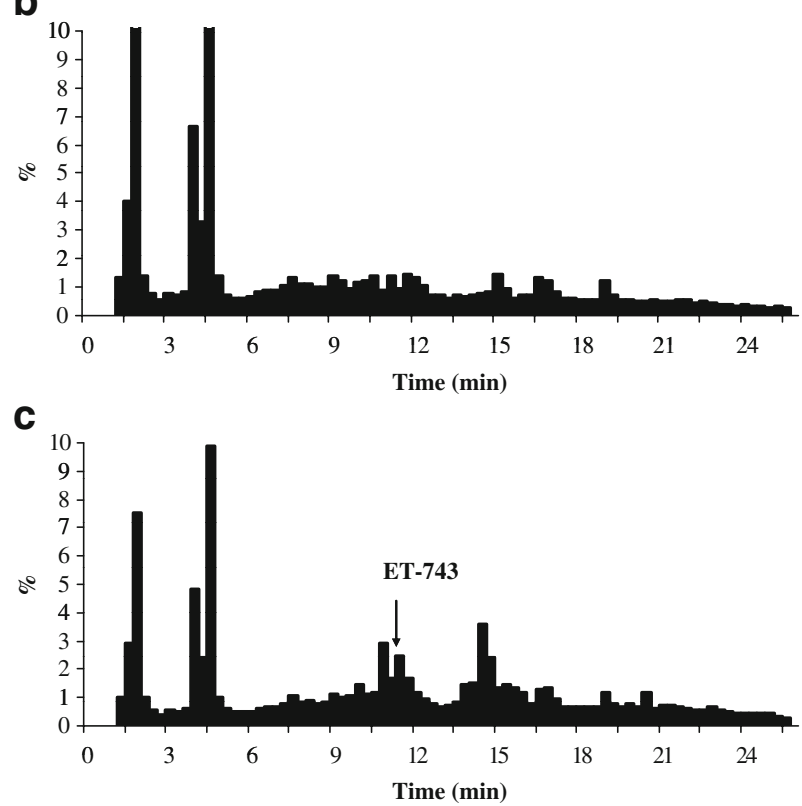

Fig. 5 Radiochromatograms of a diethyl ether extract (a) of a $0-1.5 \mathrm{~h}$ bile sample, the remaining aqueous phase (b) and the composite of both (c) displaying the metabolic profile of $\left[{ }^{14} \mathrm{C}\right]$ trabectedin after administration to a single male wild-type mouse 
may be P-gp substrates. The bile experiment showed that the liver excreted a large number of radioactive trabectedin metabolites, in agreement with the human metabolic profile of trabectedin $[15,16]$. Besides a range of more polar compounds, we also observed several hydrophobic metabolites in bile, which is different from the reports in humans. Due to the low quantities of these metabolites, further structural characterization (e.g. by mass spectrometry) was not feasible. Earlier in vitro studies have shown that human metabolism of trabectedin is mediated by CYP450 enzymes with a major role for $3 \mathrm{~A} 4$ and minor contributions of $2 \mathrm{C} 9$, 2C19, 2D6, and 2E1 [13, 17]. The expression of CYP450 enzymes (including CYP3A2, the rodent counterpart of human CYP3A4) in rats and mice is known to be sexdependent $[34,35]$. Moreover, there are reports of changes in CYP450 expression in $m d r 1 a / 1 b(-/-)$ relative to wildtype mice [36]. In addition, expression of other transporters may also be modified in $m d r l a / 1 b(-/-)$ as compared to wild-type mice. A recent study suggested a role for the multidrug resistance related proteins (Mrp2, Mrp3 and Mrp4 in the hepatotoxicity of trabectedin [37].

Consequently, gender and strain differences in CYP450 enzymes expression resulting in variations in the metabolic fate of trabectedin may partly explain the observed differences in toxicity at similar plasma exposures. In future studies, it may be advisable to determine the expression levels of CYP enzymes and other known drug transporters.

Our experiments confirm earlier reports that hepatotoxicity of trabectedin in mice is non-cumulative and reversible [38]. This is in parallel with humans [39-41] but opposed to rats where plasma ASAT, AP and bile acid levels remained elevated for several months after dosing [12, 42, 43]. Therefore, the mouse appears to be a better species than rats as a model of trabectedin-induced hepatotoxicity trabectedin. However, metabolic profiles highly differ between species, with major differences between mice, dogs and rats, and greater similarity between human and primate metabolism, and therefore the best model was reported to be a monkey model $[44,45]$. The decreased hepatotoxic response of wild-type mice after a repeated injection of trabectedin may be due to up-regulation of detoxifying pathways. Interestingly, we did not observe a decreased hepatotoxicity in mdrla/lb(-/-) mice, which may suggest the involvement of P-gp. Interestingly, up-regulation of canalicular P-gp has been observed in rats after trabectedin administration [42], even if the expression of other pumps and enzymes may have been altered. It is unlikely that upregulation of P-gp results in a markedly enhanced hepatobiliary excretion of trabectedin, but it may aid in the elimination of other, possibly toxic, metabolites of trabectedin. Increased efflux of toxic metabolites could explain reduced toxicity in the wild-type mice and slightly increased toxicity in mdrla/lb(-/-) mice after repeated dosing.
The degree of hepatotoxicity was also determined by gender. However, the hepatotoxicity is not a dose-limiting event per se. While both strains were dosed at $250 \mu \mathrm{g} / \mathrm{kg}$ (the MTD in both strains), female wild-type mice experienced (almost) no hepatotoxicity, whereas we observed serious hepatoxicity in female $m d r l a / 1 b(-/-)$ mice. Apparently, there are other trabectedin toxicities resulting in a decreased well-being, and ultimately death. Pathology of the animals revealed other toxicities, however, none of these were clearly dose limiting either. The bone marrow depletion observed 4 days after administration, which had recovered at day 14 , is in keeping with the dose limiting toxicities observed in humans (thrombocytopenia, neutropenia, pancytopenia) [12]. Pathological examination of $m d r l a / 1 b(-/-)$ and wild-type mice revealed some striking differences in toxicity at the organ-level. The observations in the liver are relatively mild and in line with the reversible nature of the hepatotoxicity. The degeneration of the kidney tubules and the degenerative cardiomyopathy in female $m d r l a / 1 b(-/-)$ mice is suggestive of a protective role for P-gp. However, the involvement of other enzymes, whose expression may be affected by the absence of P-gp, cannot be ruled out. The absence of similar pathologic effects in male $m d r l a / 1 b(-/-)$ mice may be due to the lower dose administered (MTD $150 \mu \mathrm{g} / \mathrm{kg}$ relative to $250 \mu \mathrm{g} / \mathrm{kg}$ in females).

In conclusion, P-gp is important for the in vivo disposition of trabectedin as its expression decreased the distribution into the testis and the brain. However, P-gp does not significantly influence the clearance of trabectedin. Consequently, differences in toxicities between wild-type and $m d r l a / 1 b(-/-)$ mice could not adequately be explained by differences in plasma exposure of unchanged drug. This suggests that either tissue-specific distribution of trabectedin, or metabolites of trabectedin determine its toxicity profile.

Acknowledgements The authors gratefully acknowledge the statistical assistance of Guus Hart and the biotechnical assistance of Ton Schrauwers, and Martin van der Valk for providing expert pathology reports. We also thank the University of Pittsburgh Cancer Institute Hematology/Oncology Writing Group for constructive suggestions regarding the manuscript.

Funding Source This work was paid for by PharmaMar, Colmenar Viejo, Madrid, Spain. The study sponsor had a chance to make recommendations to the investigator-initiated study proposal. The sponsor had no input in data collection, analysis, and interpretation, but did have input in the reviewing of the report.

\section{References}

1. Blay JY, Le Cesne A, Verweij J, Scurr M, Seynaeve C, Bonvalot S, Hogendoorn P, Jimeno J, Evrard V, Van Glabbeke M, Judson I (2004) A phase II study of ET-743/trabectedin ('Yondelis') for patients with advanced gastrointestinal stromal tumours. Eur J Cancer 40:1327-1331 doi:10.1016/j.ejca.2004.02.005 
2. Garcia-Carbonero R, Supko JG, Manola J, Seiden MV, Harmon D, Ryan DP, Quigley MT, Merriam P, Canniff J, Goss G, Matulonis U, Maki RG, Lopez T, Puchalski TA, Sancho MA, Gomez J, Guzman C, Jimeno J, Demetri GD (2004) Phase II and pharmacokinetic study of ecteinascidin 743 in patients with progressive sarcomas of soft tissues refractory to chemotherapy. J Clin Oncol 22:1480-1490 doi:10.1200/JCO.2004.02.098

3. Laverdiere C, Kolb EA, Supko JG, Gorlick R, Meyers PA, Maki RG, Wexler L, Demetri GD, Healey JH, Huvos AG, Goorin AM, Bagatell R, Ruiz-Casado A, Guzman C, Jimeno J, Harmon D (2003) Phase II study of ecteinascidin 743 in heavily pretreated patients with recurrent osteosarcoma. Cancer 98:832-840 doi: $10.1002 /$ cncr. 11563

4. Committee for Medicinal Products for Human Use Product Information 17/03/2008 Yondelis-H-C-773-IB-02. European Medicines Agency 2008

5. Carter NJ, Keam SJ (2007) Trabectedin: a review of its use in the management of soft tissue sarcoma and ovarian cancer. Drugs 67:2257-2276 doi:10.2165/00003495-200767100-00009

6. Moore BM, Seaman FC, Wheelhouse RT, Hurley LH (1998) Mechanism for the catalytic activation of ecteinscidin 743 and its subsequent alkylation of guanine N2. J Am Chem Soc 120:2490 2491 doi:10.1021/ja974109r

7. Pommier Y, Kohlhagen G, Bailly C, Waring M, Mazumder A, Kohn KW (1996) DNA sequence- and structure-selective alkylation of guanine N2 in the DNA minor groove by ecteinascidin 743 , a potent antitumor compound from the Caribbean tunicate Ecteinascidia turbinata. Biochemistry 35:13303-13309 doi:10.1021/ bi960306b

8. Kanzaki A, Takebayashi Y, Ren XQ, Miyashita H, Mori S, Akiyama S, Pommier Y (2002) Overcoming multidrug drug resistance in P-glycoprotein/MDR1-overexpressing cell lines by ecteinascidin 743. Mol Cancer Ther 1:1327-1334

9. Minuzzo M, Marchini S, Broggini M, Faircloth G, D'Incalci M, Mantovani R (2000) Interference of transcriptional activation by the antineoplastic drug ecteinascidin-743. Proc Natl Acad Sci USA 97:6780-6784 doi:10.1073/pnas.97.12.6780

10. Jin S, Gorfajn B, Faircloth G, Scotto KW (2000) Ecteinascidin 743, a transcription-targeted chemotherapeutic that inhibits MDR1 activation. Proc Natl Acad Sci USA 97:6775-6779 doi:10.1073/ pnas.97.12.6775

11. Synold TW, Dussault I, Forman BM (2001) The orphan nuclear receptor SXR coordinately regulates drug metabolism and efflux. Nat Med 7:584-590 doi:10.1038/87912

12. van Kesteren C, de Vooght MM, Lopez-Lazaro L, Mathot RA, Schellens JHM, Jimeno JM, Beijnen JH (2003) Yondelis (trabectedin, ET-743): the development of an anticancer agent of marine origin. Anticancer Drugs 14:487-502 doi:10.1097/ 00001813-200308000-00001

13. Reid JM, Kuffel MJ, Ruben SL, Morales JJ, Rinehart KL, Squillace DP, Ames MM (2002) Rat and human liver cytochrome P-450 isoform metabolism of ecteinascidin 743 does not predict gender-dependent toxicity in humans. Clin Cancer Res 8:29522962

14. Sparidans RW, Rosing H, Hillebrand MJ, Lopez-Lazaro L, Jimeno JM, Manzanares I, van Kesteren C, Cvitkovic E, van Oosterom AT, Schellens JHM, Beijnen JH (2001) Search for metabolites of ecteinascidin 743, a novel, marine-derived, anti-cancer agent, in man. Anticancer Drugs 12:653-666 doi:10.1097/00001813200109000-00003

15. Beumer JH, Rademaker-Lakhai JM, Rosing H, Hillebrand MJ, Bosch TM, Lopez-Lazaro L, Schellens JH, Beijnen JH (2007) Metabolism of trabectedin (ET-743, Yondelis) in patients with advanced cancer. Cancer Chemother Pharmacol 59:825-837 doi:10.1007/s00280-006-0342-2
16. Beumer JH, Rademaker-Lakhai JM, Rosing H, Lopez-Lazaro L, Beijnen JH, Schellens JH (2005) Trabectedin (Yondelis, formerly ET-743), a mass balance study in patients with advanced cancer. Invest New Drugs 23:429-436 doi:10.1007/s10637-005-2902-4

17. Brandon EFA In vitro characterization of the human biotransformation of marine derived anti-cancer drugs. 2004 Utrecht University, Faculty of Pharmaceutical Sciences, thesis

18. Beumer JH, Buckle T, Ouwehand M, Franke NE, Lopez-Lazaro L, Schellens JH, Beijnen JH, van Tellingen O (2007) Trabectedin (ET-743, Yondelis) is a substrate for P-glycoprotein, but only high expression of P-glycoprotein confers the multidrug resistance phenotype. Invest New Drugs 25:1-7 doi:10.1007/s10637-0067773-9

19. D'Incalci M, Jimeno J (2003) Preclinical and clinical results with the natural marine product ET-743. Expert Opin Investig Drugs 12:1843-1853

20. Jimeno J, Maki R, Casali PG, Faircloth G, Martinez N, Nieto A, Canigueral S (2003) Therapeutic impact of ET-743 (Yondelis ${ }^{\circledR}$, Trabectidin) a new marine derived compound in Sarcoma. Curr Opin Orthop 14:419-428, Abstract doi:10.1097/00001433200312000-00011

21. Takebayashi Y, Pourquier P, Zimonjic DB, Nakayama K, Emmert S, Ueda T, Urasaki Y, Kanzaki A, Akiyama SI, Popescu N, Kraemer KH, Pommier Y (2001) Antiproliferative activity of ecteinascidin 743 is dependent upon transcription-coupled nucleotide-excision repair. Nat Med 7:961-966 doi:10.1038/ 91008

22. Schinkel AH (1999) P-Glycoprotein, a gatekeeper in the bloodbrain barrier. Adv Drug Deliv Rev 36:179-194 doi:10.1016/ S0169-409X(98)00085-4

23. Schinkel AH, Mayer U, Wagenaar E, Mol CA, van Deemter L, Smit JJ, van der Valk MA, Voordouw AC, Spits H, van Tellingen O, Zijlmans JM, Fibbe WE, Borst P (1997) Normal viability and altered pharmacokinetics in mice lacking mdr1-type (drug-transporting) Pglycoproteins. Proc Natl Acad Sci USA 94:4028-4033 doi:10.1073/ pnas.94.8.4028

24. van Asperen J, van Tellingen O, Tijssen F, Schinkel AH, Beijnen $\mathrm{JH}$ (1999) Increased accumulation of doxorubicin and doxorubicinol in cardiac tissue of mice lacking mdrla P-glycoprotein. Br J Cancer 79:108-113 doi:10.1038/sj.bjc.6690019

25. Schinkel AH, Wagenaar E, van Deemter L, Mol CA, Borst $P$ (1995) Absence of the mdr1a P-Glycoprotein in mice affects tissue distribution and pharmacokinetics of dexamethasone, digoxin, and cyclosporin A. J Clin Invest 96:1698-1705 doi:10.1172/JCI118214

26. Meissner K, Sperker B, Karsten C, Zu Schwabedissen HM, Seeland U, Bohm M, Bien S, Dazert P, Kunert-Keil C, Vogelgesang S, Warzok R, Siegmund W, Cascorbi I, Wendt M, Kroemer HK (2002) Expression and localization of Pglycoprotein in human heart: effects of cardiomyopathy. J Histochem Cytochem 50:1351-1356

27. Lin JH, Yamazaki M (2003) Role of P-glycoprotein in pharmacokinetics: clinical implications. Clin Pharmacokinet 42:59-98 doi:10.2165/00003088-200342010-00003

28. Rosing H, Hillebrand MJ, Jimeno JM, Gomez A, Floriano P, Faircloth G, Henrar RE, Vermorken JB, Cvitkovic E, Bult A, Beijnen JH (1998) Quantitative determination of Ecteinascidin 743 in human plasma by miniaturized high-performance liquid chromatography coupled with electrospray ionization tandem mass spectrometry. J Mass Spectrom 33:1134-1140 doi:10.1002/ (SICI)1096-9888(1998110)33:11<1134::AID-JMS730>3.0.CO;2-S

29. Sparreboom A, van Asperen J, Mayer U, Schinkel AH, Smit JW, Meijer DK, Borst P, Nooijen WJ, Beijnen JH, van Tellingen O (1997) Limited oral bioavailability and active epithelial excretion of paclitaxel (Taxol) caused by P-glycoprotein in the intestine. Proc Natl Acad Sci USA 94:2031-2035 doi:10.1073/pnas.94.5.2031 
30. Smit JW, Schinkel AH, Weert B, Meijer DK (1998) Hepatobiliary and intestinal clearance of amphiphilic cationic drugs in mice in which both mdrla and mdrlb genes have been disrupted. $\mathrm{Br} \mathrm{J}$ Pharmacol 124:416-424 doi:10.1038/sj.bjp.0701845

31. Smit JW, Schinkel AH, Muller M, Weert B, Meijer DK (1998) Contribution of the murine mdrla P-glycoprotein to hepatobiliary and intestinal elimination of cationic drugs as measured in mice with an mdrla gene disruption. Hepatology 27:1056-1063 doi:10.1002/hep.510270422

32. van Tellingen O (2001) The importance of drug-transporting Pglycoproteins in toxicology. Toxicol Lett 120:31-41 doi:10.1016/ S0378-4274(01)00304-6

33. van Asperen J, van Tellingen O, Beijnen JH (2000) The role of mdr1a P-glycoprotein in the biliary and intestinal secretion of doxorubicin and vinblastine in mice. Drug Metab Dispos 28:264-267

34. Czerniak R (2001) Gender-based differences in pharmacokinetics in laboratory animal models. Int J Toxicol 20:161-163 doi:10.1080/109158101317097746

35. Kato R, Yamazoe Y (1992) Sex-specific cytochrome P450 as a cause of sex- and species-related differences in drug toxicity. Toxicol Lett 64-65:661-667, (Spec No) doi:10.1016/0378-4274 (92) $90245-\mathrm{F}$

36. Schuetz EG, Umbenhauer DR, Yasuda K, Brimer C, Nguyen L, Relling MV, Schuetz JD, Schinkel AH (2000) Altered expression of hepatic cytochromes P-450 in mice deficient in one or more mdr1 genes. Mol Pharmacol 57:188-197

37. Lee JK, Leslie EM, Zamek-Gliszczynski MJ, Brouwer KL (2008) Modulation of trabectedin (ET-743) hepatobiliary disposition by multidrug resistance-associated proteins (Mrps) may prevent hepatotoxicity. Toxicol Appl Pharmacol 228:17-23 doi:10.1016/ j.taap.2007.11.020

38. Jimeno JM, Faircloth G, Cameron L, Meely K, Vega E, Gomez A, Fernandez Sousa Faro JM, Rinehart K (1996) Progress in the acquisition of new marine-derived anticancer compounds: development of ecteinascidin-743 (ET-743). Drugs Future 21:1155-1165
39. Taamma A, Misset JL, Riofrio M, Guzman C, Brain E, Lopez Lazaro L, Rosing H, Jimeno JM, Cvitkovic E (2001) Phase I and pharmacokinetic study of ecteinascidin-743, a new marine compound, administered as a 24-hour continuous infusion in patients with solid tumors. J Clin Oncol 19:1256-1265

40. van Kesteren C, Cvitkovic E, Taamma A, Lopez-Lazaro L, Jimeno JM, Guzman C (2000) Math t RA, Schellens JH, Misset JL, Brain E, Hillebrand MJ, Rosing H, Beijnen JH: Pharmacokinetics and pharmacodynamics of the novel marine-derived anticancer agent ecteinascidin 743 in a phase I dose-finding study. Clin Cancer Res 6:4725-4732

41. Twelves C, Hoekman K, Bowman A, Vermorken JB, Anthoney A, Smyth J, van Kesteren C, Beijnen JH, Uiters J, Wanders J, Gomez J, Guzman C, Jimeno J, Hanauske A (2003) Phase I and pharmacokinetic study of Yondelis (Ecteinascidin-743; ET-743) administered as an infusion over $1 \mathrm{~h}$ or $3 \mathrm{~h}$ every 21 days in patients with solid tumours. Eur J Cancer 39:1842-1851 doi:10.1016/S0959-8049(03)00458-1

42. Donald S, Verschoyle RD, Edwards R, Judah DJ, Davies R, Riley J, Dinsdale D, Lopez Lazaro L, Smith AG, Gant TW, Greaves P, Gescher AJ (2002) Hepatobiliary damage and changes in hepatic gene expression caused by the antitumor drug ecteinascidin-743 (ET-743) in the female rat. Cancer Res 62:4256-4262

43. Mirsalis JC, Schindler-Horvat JE, Tomaszewski JE, Fairchild DG, Hill JR, Tyson CA, Schweikart KM, Turner NA, Sells D, Donohue SJ (1996) Preclinical toxicology studies of Ecteinascidin 743. Proc Am Assoc Cancer Res 37:375 Abstract

44. Beumer JH, Schellens JH, Beijnen JH (2005) Hepatotoxicity and metabolism of trabectedin: a literature review. Pharmacol Res 51:391-398

45. Vermeir M, Hendrickx J, Hurkmans R, van Houdt J, Zwijsen C, Bode N, Aviles P, Manzanares I, Mannens G, Meuldermans W, de Coster R (2003) An interspecies comparison of the metabolism of the anticancer agent Yondelis ${ }^{\mathrm{TM}}$ (trabectedin, ET-743). Chemicke Listy 97:S195-S196 Abstract 